\title{
Effect of Organic and Bio-fertilization on Growth and Fruiting of
} Sakkoty Date Palm

*El-Salhy, A.M. ; A.A. Badawy" ; E.G. Gadalla ${ }^{2}$ and H.K.Hassan ${ }^{2}$

${ }^{1}$ Pomoloty Dept., Fac. Agric., Assiut University, Assiut, Egypt

${ }^{2}$ Central Palm Laboratory, Agriculture Research Center Agric.

*Email: Abdelfattah.elsalhy@agr.aun.edu.eg

\section{Abstract}

The beneficial effects of organic manure singly or combined with mineral$\mathrm{N}$ (min.) and bio-fertilizers (bio.) on growth, nutritional status, yield and fruit quality of Sakkoty date palm grown in Research farm of Agricultural research station at Kom Ambo, Aswan Governorate, Egypt, were studied during the two successive seasons 2019 and 2020. The experimental palms were arranged in complete randomized design with six treatments and three replications one palm per each.

It is evident from the obtained results that applying organic-N either alone or combined with mineral-N (double form), as well as mineral-N and biofertilization (triple form) was very effective in improving growth and nutritional status as well as yield and dates quality compared to fertilization with mineral nitrogen only. Fertilizing with triple form (min., organic and bio.) gave the highest values of the studied traits compared to other fertilization treatments.

So, the study suggested that using triple form (30\% mineral-N, 35\% organic and $35 \%$ bio-fertilization improved the vegetative growth yield and dates quality. In addition, it reduced environmental pollution problems.

Keywords: Organic, Bio-fertilizers, growth, fruit quality, date palm.

\section{Introduction}

The date palm is one of the most important fruit crops that has been a source of nutrition and shelter against harsh condition. In many desert areas, dates have been used as a staple food for hundreds of years. Dates are a rich source of sugars and numerous minerals that are necessary for life and essentially required for good health (Mertz, 1981 and Wrigley, 1995). Egypt is considered to be one of the major date producing countries in the worlds (FAO, 2014). Date palm is grown in both Nile Valley and desert districts in Egypt. Aswan ranked the fourth position among the Egyptian Governorates. Dry date palm cultivars covered all the acreage of total cultivated in Aswan governorate.

Sakkoty date palm is the major dry date palm grown under Aswan condition. Poor yield of Sakkoty date palm grown under Aswan region is considered a problem. This is attributed to unbalancing nitrogen nutrition. The main cause of the problem may be due to the use of over mineral-N application that is considered as air, soil and water polluting agents (Devlin and Withdam, 1983 and ElSalhy, 2004). Adjusting inorganic N fertilization partially by using organic manures enriched with biofertilization is necessary to overcome this problem (Verna, 1990 and Russa and Berlyn, 1990). 
Nitrogen fertilization is one of the important tools to increase the fruiting of yield in fruit trees. The efficiency of nitrogen fertilizer under field conditions and surface irrigated soils rarely exceeds $50 \%$ and is usually ranged between 30 and 40\% (Sahrawat, 1979). Low efficiency may be due to losses of $\mathrm{N}$ from soils as nitrate and nitrite by leaching or going up as nitrogen gases through nitrate reduction by volatilization. So, many problems were caused, such as nitrate pollution of ground water and environment. On the other side, these huge amounts of chemicals depress the activities of both nitrogen fixation bacteria and phosphorus bacteria which only work, actively, at low concentration of these substances (Kannaiyan, 2002). In addition, they can alter the composition of fruits, vegetables and root crops and decrease their contents of vitamins, minerals and other useful compounds. There is a very great danger that harmful residues may remain in food (Bogatyre, 2000).

So, organic fertilization for fruit crops became in the last few decades a good alternative to chemical fertilization to depress pollution in the environment and to produce a safe and nutritive food that is good for health (Nijjar, 1985 and Miller et al., 1990). In addition, the growers apply organic and bio-fertilizer to improve soil physical, chemical and biological properties as well as to increase nutrient availability (Yagodin, 1984; Darwish et al., 1995; El-Salhy 2004 and Subba Rao, 2004). The use of organic materials as $\mathrm{N}$ source has been considered as a best management because organic $\mathrm{N}$ is released to the trees more gradually than water soluble inorganic $\mathrm{N}$ fertilizers (Nijjar, 1985). Similarly, soil fertility can be managed using organic fertilizers, crop rotation and association along with composting and recycling of the organic matter (Kenny and Hassan, 2006).

Many investigators emphasized the importance of the organic and bio-fertilization to increase the growth and fruiting of date palm trees (Abdel-Hameed and Ragab, 2004; ElAssar, 2005; El-Salhy et al., 2008; Alwasfy and El-Khawaga, 2008; Osman, 2009; Ahmed et al., 2011; Saad et al., 2011; Abou-Baker, 2015; Omar, 2015; El-Sayed et al., 2016; Abdel-Kafy, 2018 and SayedMaryam, 2018).

So, the objective of this investigation was to study the possibility of using organic or bio-fertilization partially instead of completed mineral fertilization on growth and fruiting of Sakkoty date palm.

\section{Materials and Methods}

The experiment was carried out during two successive growing seasons 2019 and 2020 on 35 years old Sakkoty date palms. The selected palms were grown in Research farm in Agricultural research station that located at Kom Ambo, Aswan Governorate, Egypt. The laboratory work was conducted in Regional Agricultural Research Station of Aswan. The texture of the soil is silty clay. Analysis of the soil was done according to Wilde et al. (1985) and the obtained data are given in Table (1). 
Table 1. Mechanical, physical and chemical analysis of the tested orchard soil.

\begin{tabular}{|l|c|l|c|}
\hline \multicolumn{1}{|c|}{ Characters } & Values & \multicolumn{1}{c|}{ Characters } & Values \\
\hline Particle size distribution & & $\mathrm{P}(\mathrm{ppm}$ Olsen method) & 20.00 \\
\hline Sand \% & 10.60 & $\mathrm{~K}(\mathrm{ppm}$ ammonium acetate) & 419.00 \\
\hline Silt \% & 58.00 & $\mathrm{Mg}(\mathrm{ppm}$ & 79.00 \\
\hline Clay \% & 31.40 & $\mathrm{~S}(\mathrm{ppm})$ & 6.90 \\
\hline Texture grade & Silty clay & $\mathrm{B}(\mathrm{ppm}$ hot water extractable) & 0.27 \\
\hline $\mathrm{pH}(1: 2.5$ extract) & 8.00 & $\mathrm{EDTA}$ extractable micronutrients $(\mathrm{ppm})$ & \\
\hline E.c $\left(1: 2.5\right.$ extract) $\mathrm{mmhos} / 1 \mathrm{~cm} / 25^{\circ} \mathrm{C}$ & 0.91 & $\mathrm{Zn}$ & 1.31 \\
\hline Organic matter \% & 2.09 & $\mathrm{Fe}$ & 11.00 \\
\hline $\mathrm{CaCO}_{3} \%$ & 1.22 & $\mathrm{Mn}$ & 10.18 \\
\hline Macronutrients values & & $\mathrm{Cu}$ & 1.60 \\
\hline Total $\mathrm{N} \%$ & 0.11 & & \\
\hline
\end{tabular}

Eighteen healthy palms nearly similar in growth vigour were selected. Regular agricultural practices except nitrogen fertilization were carried out as usual. The leaf/bunch ratio was adjusted at the end of the blooming season to meet their value of $8: 1$. Artificial pollination was uniformly performed in respect of source, date and method.
The experiment involved six treatments representing various levels of nitrogen fertilization (inorganic and bio-organic). Each treatment except the checked treatment was under the same recommended $\mathrm{N}$ level of $1000 \mathrm{~g} \mathrm{~N} / \mathrm{palm} / \mathrm{year}$, as shown in Table (2).

Table 2. The amount of nitrogen in organic, bio-mineral-form applied in the studied treatments.

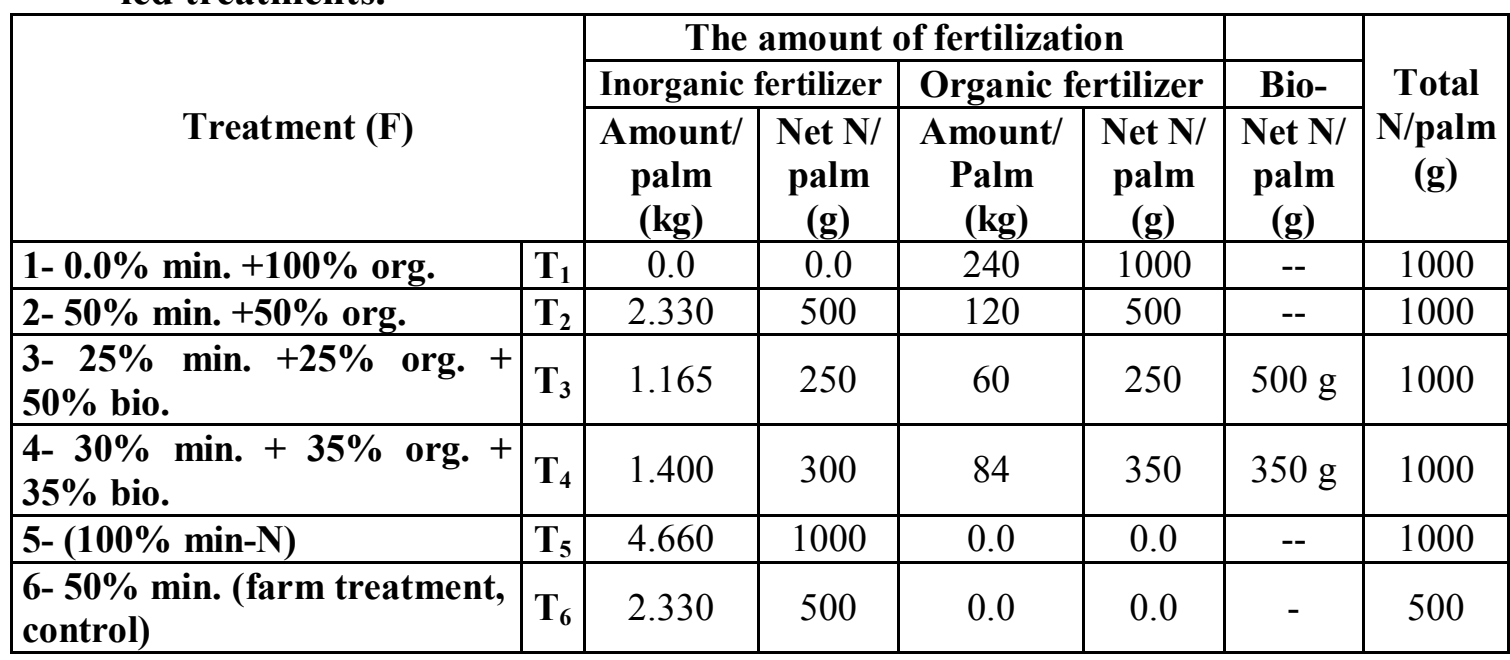

Nitrogen in mineral source is used as ammonium sulphate form $(21.5 \% \quad \mathrm{~N})$ while organic-N was added as farmyard manure $(0.42 \%$ $\mathrm{N})$. Farmyard manure was added in one dose in two exchangeable holes, $1 \mathrm{~m}$ apart from palm trunk in December. Ammonium sulphate was applied at three equal batches in March, May and July of each season.

Nitrobien is a commercial biofertilizer was mixed with moist sand and added in soil holes around the trunk of palm, then irrigated immediately. Nitrobien was applied at two 
equal batches on the middle of February and May.

The design of the experiment was completely randomized with three replicates, one palm per each.

The following parameters were determined to evaluate the effects of different fertilization treatments on growth, nutrient status and fruiting.

\section{1- Vegetative growth:}

Average number of newly grown leaves was counted at the end of growing season. In addition, four mature leaves (fronds) around fruiting zone (each embracing a bunch) were chosen on each palm to determine, leaf length (m). Four pinnae were taken from the middle part of each leaf to determine pinnae area $\left(\mathrm{cm}^{2}\right)$ as follows:

leaflet area $=$ (length $\mathrm{x}$ maximum width $x$ 0.84) according to Shabana and Antoun (1980). Then, the whole leaf area $\left(\mathrm{m}^{2}\right)$ was determined from multiplying the leaflet area by the number of leaflets/leaf.

\section{2- Percentage of $N, P$ and $K$ in leaf:}

Samples of pinnae from each replicate were collected at mid of November. The pinnae were washed with tap water, distilled water, airdried, even-dried at $70^{\circ} \mathrm{C}$ to constant weight. The dry material was ground in a stainless well and $0.2 \mathrm{~g}$ of each sample was digested using concentrated sulphoric acid and 30\% hydrogen peroxide for overnight, percentage of $\mathrm{N}, \mathrm{P}$ and $\mathrm{K}$ (on dry weight basis) were determined in the digested solution according to Wilde et al. (1985).

\section{3- Yield and its components:}

A- The spathes number of each date palm was recorded at the end of blooming season.

\section{B- Fruit retention:}

It was calculated at harvest from number of fruits harvested divided by total number of fruits set and multiplied by hundred using the following equations:

Fruit retention $(\phi)=\frac{\text { Number of retalned frults on the strand }}{\text { Number of retained fruit }+ \text { Number of flowers scars }} \times 100$

\section{C- Bunch weight and yield/palm:}

At the harvest time, bunches of each palm were picked and weighed, then the yield/palm $(\mathrm{kg})$ was recorded.

\section{4- Fruit characteristics:}

Sample of 50 fruits were taken randomly from each replicate to determine some physical and chemical properties.

\section{A- Physical characteristics:}

These characteristics included the determination of fruit weight, fruit dimension, flesh percentage, flesh thickness and fruit moisture percentage.

\section{B - Chemical characteristics:}

These characteristics included, total soluble solids (TSS), sugar contents and total acidity of fruit juice as outlined in A.O.A.C. (1995).

All the obtained data were tabulated and analyzed to the proper statistical analysis according to Gomez and Gomez (1984) and Snedecor and Cochran (1990). The differences between treatment means were compared by Duncan's multiple range test at $5 \%$ level of probability to Duncan (1955).

\section{Results}

\section{1 - Vegetative growth:}

It is evident from the data in Tables (3 and 4) that organic-N form either alone or combined with mineral-N and bio-forms significantly increased the growth traits, i.e. leaf length and area of leaflet and leaf, then significantly increased the total 
leaf surface area per palm. Moreover, all combined forms as well as organic fertilization significantly increased the leaf $\mathrm{N}, \mathrm{P}$ and $\mathrm{K}$ percentage compared to fertilization with 100 or $50 \%$ of nitrogen doses as mineral-N only.

The highest values of leaf area and leaf mineral contents were recorded on the palms that were fertilized with triple form (25-30 mineral, $25-35 \%$ organic and 35-50 bio-form, $\mathrm{T}_{3}, \mathrm{~T}_{4}$ ). On other hand, the least values of these studied traits were recorded on palm that fertilized with $50 \%$ mineral-N (farm treatment, $\mathrm{T}_{6}$ ). The highest leaf area was $2.44 \& 2.33$ $\mathrm{m}^{2}$ and leaf-N was $1.84 \& 2.08 \%$ due to the triple form use $(25 \% \mathrm{~m}, 25 \%$ organic and $50 \%$ bio-form, $\mathrm{T}_{3}$ ) during the two studied seasons, respectively. Contrarily, the least values for leaf area were $1.88 \& 1.77 \mathrm{~m}^{2}, 2.16 \&$ $2.03 \mathrm{~m}^{2}$ and leaf $\mathrm{N}$ were $1.36 \&$ $1.48 \%$ and $1.53 \& 1.75 \%$ on the palms treated with $50 \%$ mineral-N $\left(\mathrm{T}_{6}\right)$ and $100 \%$ mineral $\mathrm{N}\left(\mathrm{T}_{5}\right)$ during the two studied seasons, respectively. Hence the increment percentage of leaf area were $29.79 \& 31.64 \%, 12.96$ $\& 14.78 \%$ and leaf $\mathrm{N} \%$ were 35.29 $\& 40.54 \%$ and $20.26 \& 18.86 \%$ due to fertilization with triple form ( $25 \%$ $\mathrm{m}, 25 \%$ org. and 50 bio-form) compared to fertilization with $50 \%$ or $100 \%$ mineral-N during the two studied seasons, respectively. No significant differences were found due to fertilization with either organic alone, double $(50 \% \mathrm{~m}$ and 50 organic) or triple forms, whereas, there is a significant difference between using $100 \%$ or $50 \%$ mineral-N. The best results with regard to growth and nutritional leaf of Sakkoty date palm were obtained due to its fertilization with the triple form either $25 \mathrm{~m}+24$ org $+50 \%$ bio $\left(\mathrm{T}_{3}\right)$ or $30 \mathrm{~m}, 35 \%$ org. and $35 \%$ bio-form $\left(\mathrm{T}_{4}\right)$.

Table 3. Effect of different nitrogen fertilization sources on vegetative growth of Sakkoty date palm during 2019 and 2020 seasons.

\begin{tabular}{|c|c|c|c|c|c|c|c|c|c|}
\hline & \multicolumn{2}{|c|}{$\begin{array}{l}\text { No. of New } \\
\text { leaves }\end{array}$} & \multicolumn{2}{|c|}{$\begin{array}{l}\text { Leaf length } \\
\text { (m) }\end{array}$} & \multicolumn{2}{|c|}{$\begin{array}{l}\text { No. of leaf- } \\
\text { let/leaf }\end{array}$} & \multicolumn{2}{|c|}{$\begin{array}{l}\text { Leaflet area } \\
\left(\mathrm{cm}^{2}\right)\end{array}$} \\
\hline & & 2019 & 2020 & 2019 & 2020 & 2019 & 2020 & 2019 & 2020 \\
\hline $\begin{array}{l}1-0.0 \% \text { min. }+100 \% \\
\text { org. }\end{array}$ & $\left(T_{1}\right)$ & 32 & A & $3.46 \mathrm{~A}$ & $3.33 \mathrm{~A}$ & $66 \mathrm{~A}$ & $205 \mathrm{~A}$ & A & $113 \mathrm{~A}$ \\
\hline $2-50 \%$ min. $+50 \%$ org. & & $32.4 \mathrm{~A}$ & & $58 \mathrm{~A}$ & & $210 \mathrm{~A}$ & $05 \mathrm{~A}$ & 11 & ? \\
\hline$+25 \%$ org. & $\left(T_{3}\right)$ & 6 B & A & $3.32 \mathrm{~A}$ & $5 \mathrm{~B}$ & $6 \mathrm{~A}$ & $04 \mathrm{~A}$ & $3.9 \mathrm{~A}$ & $114.7 \mathrm{~A}$ \\
\hline$+35 \%$ org. & $\left(\mathrm{T}_{4}\right)$ & 3 & A & $48 \mathrm{~A}$ & $3.32 \mathrm{~A}$ & $2 \mathrm{~A}$ & $9 \mathrm{~A}$ & $6.5 \mathrm{~A}$ & $112.6 \mathrm{~A}$ \\
\hline 5- $(1$ & & 324 & $\mathrm{AB}$ & $46 \mathrm{~A}$ & $8 \mathrm{~A}$ & $5 \mathrm{~A}$ & $11 \mathrm{~A}$ & $55.3 \mathrm{~B}$ & 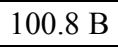 \\
\hline $\begin{array}{l}6-50 \% \\
\text { treatme }\end{array}$ & $\left(T_{6}\right)$ & $25.43 \mathrm{~B}$ & $24.67 \mathrm{~B}$ & $3.12 \mathrm{~B}$ & $2.88 \mathrm{C}$ & $190 \mathrm{~B}$ & 191 & $97.9 \mathrm{C}$ & 92 \\
\hline L.S.D. & & 25 & 2.18 & 18 & .15 & 1.7 & 10.25 & .8 & 7.5 \\
\hline
\end{tabular}

Means with different letters are significantly different at $\mathrm{P}<0.05$. 
Table 4. Effect of different nitrogen fertilization sources on leaf area, $\mathrm{N} \%, \mathrm{P} \%$ and K\% of Sakkoty date palm during 2019 and 2020 seasons.

\begin{tabular}{|c|c|c|c|c|c|c|c|c|c|}
\hline & \multicolumn{2}{|c|}{$\begin{array}{c}\text { Leaf area } \\
\left(\mathrm{m}^{2}\right)\end{array}$} & \multicolumn{2}{|c|}{ N\% } & \multicolumn{2}{|c|}{ P\% } & \multicolumn{2}{|c|}{ K\% } \\
\hline & & \begin{tabular}{|l|}
2019 \\
\end{tabular} & 2020 & 2019 & 2020 & 2019 & 2020 & 2019 & 2020 \\
\hline $1-0.0$ & $\left(T_{1}\right)$ & $2.39 \mathrm{~A}$ & $2.29 \mathrm{~A}$ & $1.67 \mathrm{~B}$ & $1.88 \mathrm{~B}$ & $0.210 \mathrm{~A}$ & $0.227 \mathrm{AB}$ & $1.13 \mathrm{~A}$ & $1.20 \mathrm{~A}$ \\
\hline $2-50 \%$ min. $+50 \%$ org. & $\left(T_{2}\right)$ & $2.41 \mathrm{~A}$ & $2.26 \mathrm{~A}$ & $1.87 \mathrm{~A}$ & $2.04 \mathrm{~A}$ & $0.213 \mathrm{~A}$ & $0.234 \mathrm{AB}$ & $1.16 \mathrm{~A}$ & $1.22 \mathrm{~A}$ \\
\hline $\begin{array}{l}3-25 \% \text { min. }+25 \% \text { org. }+ \\
50 \% \text { bio. }\end{array}$ & $\left(\mathbf{T}_{3}\right)$ & $2.35 \mathrm{~A}$ & $2.33 \mathrm{~A}$ & $1.84 \mathrm{~A}$ & $2.08 \mathrm{~A}$ & $0.220 \mathrm{~A}$ & $0.239 \mathrm{~A}$ & $1.16 \mathrm{~A}$ & $1.23 \mathrm{~A}$ \\
\hline $\begin{array}{l}\text { 4- } 30 \% \text { min. }+35 \% \text { org. }+ \\
35 \% \text { bio. }\end{array}$ & $\left(\mathbf{T}_{4}\right)$ & $2.44 \mathrm{~A}$ & $2.21 \mathrm{~A}$ & $1.82 \mathrm{~A}$ & $2.03 \mathrm{~A}$ & $0.218 \mathrm{~A}$ & $0.241 \mathrm{~A}$ & $1.18 \mathrm{~A}$ & $1.22 \mathrm{~A}$ \\
\hline $5-(100 \%$ min-N $)$ & $\left(T_{5}\right)$ & $2.16 \mathrm{~B}$ & $2.03 \mathrm{~B}$ & $1.53 \mathrm{C}$ & $1.75 \mathrm{C}$ & $0.189 \mathrm{~B}$ & $0.216 \mathrm{~B}$ & $1.03 \mathrm{~B}$ & $1.12 \mathrm{~B}$ \\
\hline $6-50 \% \mathrm{~m}$ & $\left(\mathbf{T}_{6}\right)$ & $1.88 \mathrm{C}$ & $1.77 \mathrm{C}$ & $1.36 \mathrm{D}$ & $1.48 \mathrm{D}$ & $0.146 \mathrm{C}$ & $0.165 \mathrm{C}$ & $0.88 \mathrm{C}$ & $1.02 \mathrm{C}$ \\
\hline L.S.D. & & 0.14 & 0.15 & 0.08 & 0.09 & 0.013 & 0.018 & 0.06 & 0.07 \\
\hline
\end{tabular}

Means with different letters are significantly different at $\mathrm{P}<0.05$.

\section{2- Yield and its components:}

As shown in Table (5) fertilizing Sakkoty date palm with organic N form either alone or combined with bio and mineral-N form significantly increased the number of inflorescences born/palm, fruit set and the heavy bunch weight and consequently the yield/palm. The significantly higher values of bunch weight and yield/palm were obtained from the palms that received all amounts of $\mathrm{N}$ in triple form (organic plus bio and mineral sources). Whereas, the minimum values of bunch weight and yield/palm were related to the palms that were supplied by $100 \%$ mineral (N) $\left(\mathrm{T}_{5}\right)$ or $50 \%$ mineral-N (checked treatment, $\mathrm{T}_{6}$ ).

Also, data in the prementioned table indicated that the fertilization with triple form significantly increased the bunch weight and yield/palm compared to the use of organic only or double form (organic and mineral-N). Fertilization with $100 \%$ mineral-N significantly increased the bunch weight and yield/palm compared to using 50\% mineral-N (checked treatment).
The recorded heaviest yield were $171.50 \& 176.30 \mathrm{~kg} / \mathrm{palm}$ and $172.80 \& 176.20 \mathrm{~kg} / \mathrm{palm}$ due to fertilization by any triple form $\left(\mathrm{T}_{3}\right.$ or $\left.\mathrm{T}_{4}\right)$ during the two studied seasons, respectively. Contrarily these values on palm that fertilized with $100 \%$ mineral were $152.5 \& 100.66 \mathrm{~kg} / \mathrm{palm}$ and $111.65 \& 64.66 \mathrm{~kg} / \mathrm{palm}$ on checked palm that fertilized with $50 \%$ mineral-N during the two studied seasons. Then, the corresponding increment percentage due to the use of triple form over $100 \%$ mineral-N were $12.46 \& 75.14$ and $13.31 \& 85.04 \%$ and checked ones attained $53.61 \&$ 172.66 and $54.77 \& 172.50 \%$ during the two studied seasons, respectively.

In general terms, it seems that the fertilization in either the organic, double or triple forms leads to an increase in the yield and its regularity. In addition, these treatments induce a reduction of the difference between the number of inflorescences and yield in the two studied seasons compared to fertilization via mineral-N only that causes decrease of the yield and high variation in production between the two studied seasons. 
Table 5. Effect of different nitrogen fertilization sources on yield components of Sakkoty date palm during 2019 and 2020 seasons.

\begin{tabular}{|c|c|c|c|c|c|c|c|c|c|}
\hline & \multicolumn{2}{|c|}{$\begin{array}{c}\text { No. of } \\
\text { bunches }\end{array}$} & \multicolumn{2}{|c|}{ Fruit set \% } & \multicolumn{2}{|c|}{\begin{tabular}{|c|} 
Bunch weight \\
$(\mathrm{kg})$
\end{tabular}} & \multicolumn{2}{|c|}{$\begin{array}{c}\text { Yield/palm } \\
\text { (kg) }\end{array}$} \\
\hline & & 2019 & 2020 & 19 & 2020 & 2019 & 2020 & 2019 & 2020 \\
\hline & 1) & $23.6 \mathrm{~A}$ & $17.8 \mathrm{~B}$ & $28.6 \mathrm{~B}$ & $3 B$ & $0 \mathrm{~B}$ & $5 \mathrm{~B}$ & $65.50 \mathrm{~A}$ & \\
\hline $2-5$ & $\left(T_{2}\right)$ & $.5 \mathrm{~A}$ & $6 \mathrm{AB}$ & & & & $3 \mathrm{~B}$ & $\mathrm{~A}$ & \\
\hline$+25 \%$ org. + & $\left(T_{3}\right)$ & $23.5 \mathrm{~A}$ & $19.0 \mathrm{~A}$ & $32.1 \mathrm{~A}$ & $27.4 \mathrm{~A}$ & 7.30AB & $9.28 \mathrm{~A}$ & 171. & 176.30 \\
\hline 1. $+35 \%$ org. + & $\left(\mathbf{T}_{4}\right)$ & $3.2 \mathrm{~A}$ & $.8 \mathrm{~A}$ & & A & A & 86A & $\mathrm{A}$ & \\
\hline 5- $(10$ & $\left(T_{5}\right)$ & $24.6 \mathrm{~A}$ & $14.0 \mathrm{C}$ & $26.8 \mathrm{C}$ & $3 \mathrm{C}$ & $20 \mathrm{C}$ & $7.19 \mathrm{C}$ & $152.50 \mathrm{~B}$ & 100.080 \\
\hline $\begin{array}{r}\text { 6- } 50 \% \text { n } \\
\text { ment, }\end{array}$ & $\left(T_{6}\right)$ & $20.3 \mathrm{~A}$ & $10.6 \mathrm{D}$ & 20 & $18.95 \mathrm{C}$ & (. & $6.10 \mathrm{I}$ & $55 \mathrm{C}$ & $04.00 \mathrm{D}$ \\
\hline L.S.D. & & T.N. & 1.32 & 1.68 & 1.56 & 0.53 & 0.63 & 9.81 & 8.92 \\
\hline
\end{tabular}

Means with different letters are significantly different at $\mathrm{P}<0.05$.

\section{3 - Fruit quality:}

Data presented in Tables $(6,7$ and 8) declared that using all amounts of nitrogen dose in either organic source or combined with bio and mineral source was accompanied with improving fruit weight, dimension and flesh percentage. Their effects produce the heaviest fruit weight with no effect on seed weight and consequently increasing its thickness and flesh percentage. The heaviest fruit weights were recorded on palms that received the fertilization via triple form, $\mathrm{T}_{3}(8.28 \& 11.85$ g) and $\mathrm{T}_{4}(8.53 \& 12.25 \mathrm{~g})$, whereas, the lightest fruit weights were found on palms that received the fertilization via $100 \%$ mineral $\mathrm{T}_{5}(7.40 \&$ $9.83 \mathrm{~g})$ and $50 \%$ mineral, $\mathrm{T}_{6}(6.70 \&$ $7.20 \mathrm{~g})$ during the two studied seasons. Hence, the increment percentage of fruit weight due to the use of triple form with $100 \%$ mineral was $11.89 \& 20.55$ and $15.27 \& 24.62 \%$ and over $50 \%$ mineral was $23.58 \&$ $64.58 \& 27.31 \& 70.14 \%$ during the two studied seasons, respectively. There is no significant differences in such traits due to any triple form, or- ganic alone or double form. Whereas, using $100 \%$ mineral significantly increased these traits compared to $50 \%$ mineral (check treatment).

Moreover, fertilization with either organic, double or triple forms was accompanied with improving the quality of dates in terms of raising total soluble solids and sugars contents and in reducing the moisture and total acidity percentage. The highest improvement of these traits of fruit quality was associated with using the triple form. The highest total soluble solids $(85.0 \& 82.8 \%)$ and total sugars $(67.23 \& 64.15 \%)$ were recorded in dates of the palm that received the fertilization via triple form (25\% min, $25 \%$ organic and $50 \%$ bioform, $\mathrm{T}_{3}$, against the least ones $(65.8$ $\& 66.9 \%)$ and (54.11 \& 52.24\%) on $50 \%$ mineral (checked treatment) during the two studied seasons, respectively. Then, the increment percentage of TSS were $29.18 \& 23.77 \%$ and total sugars were $24.25 \&$ $22.80 \%$ due to using triple form compared to the checked ones during the two studied seasons, respectively. 
The best results with regard to yield and fruit quality were obtained as a result of supplying the palms with $25 \%$ mineral $35 \%$ organic and $35 \%$ bio-form nitrogen dose/palm.

Table 6. Effect of different nitrogen fertilization sources on some physical properties of Sakkoty dates during 2019 and 2020 seasons.

\begin{tabular}{|c|c|c|c|c|c|c|c|c|c|}
\hline & \multicolumn{2}{|c|}{$\begin{array}{c}\text { Fruit weight } \\
\text { (g) }\end{array}$} & \multicolumn{2}{|c|}{$\begin{array}{c}\text { Flesh } \\
(\%)\end{array}$} & \multicolumn{2}{|c|}{$\begin{array}{c}\text { Fruit length } \\
(\mathrm{cm})\end{array}$} & \multicolumn{2}{|c|}{$\begin{array}{c}\text { Fruit di- } \\
\text { ameter (cm) }\end{array}$} \\
\hline & & 2019 & 2020 & 2019 & 2020 & 2019 & 2020 & 2019 & 2020 \\
\hline 1-0. & $\left(T_{1}\right)$ & $7.78 \mathrm{~B}$ & $10.85 \mathrm{~B}$ & $87.83 \mathrm{~A}$ & $88.60 \mathrm{AB}$ & $4.88 \mathrm{~B}$ & $5.47 \mathrm{~B}$ & $1.86 \mathrm{~B}$ & $1.90 \mathrm{~B}$ \\
\hline $2-50 \%$ min. $+50 \%$ org. & $\left(T_{2}\right)$ & $92 \mathrm{~B}$ & $11.69 \mathrm{~A}$ & $88.22 \mathrm{~A}$ & $89.34 \mathrm{~A}$ & $4.91 \mathrm{~B}$ & $5.54 \mathrm{AB}$ & $1.98 \mathrm{~A}$ & $1.88 \mathrm{~B}$ \\
\hline $\begin{array}{l}\text { 3- } 25 \% \text { min. }+25 \% \text { org. }+ \\
50 \% \text { bio. }\end{array}$ & $\left(\mathbf{T}_{3}\right)$ & $28 \mathrm{~A}$ & $11.85 \mathrm{~A}$ & 88.39A & $89.89 \mathrm{~A}$ & $5.12 \mathrm{AB}$ & $5.76 \mathrm{~A}$ & $89 \mathrm{~B}$ & 8 \\
\hline $\begin{array}{l}\text { 4- } 30 \% \text { min. }+35 \% \text { org. }+ \\
35 \% \text { bio. }\end{array}$ & $\left(\mathbf{T}_{4}\right)$ & $8.53 \mathrm{~A}$ & $12.25 \mathrm{~A}$ & $87.80 \mathrm{~A}$ & $89.25 \mathrm{~A}$ & $5.26 \mathrm{~A}$ & $5.82 \mathrm{~A}$ & $1.90 \mathrm{~B}$ & $1.96 A$ \\
\hline in-N) & 5) & $.40 \mathrm{C}$ & $9.83 \mathrm{C}$ & $85.28 \mathrm{~B}$ & $86.15 \mathrm{~B}$ & $4.65 \mathrm{C}$ & $5.14 \mathrm{C}$ & $1.78 \mathrm{C}$ & 1.76 \\
\hline $\begin{array}{l}6-50 \% \text { n } \\
\text { ment, cor }\end{array}$ & $\left(\mathbf{T}_{6}\right)$ & $6.70 \mathrm{D}$ & $7.20 \mathrm{D}$ & $83.68 \mathrm{~B}$ & $85.22 \mathrm{~B}$ & $4.31 \mathrm{D}$ & $4.62 \mathrm{D}$ & $1.64 \mathrm{D}$ & 1.68 \\
\hline L.S.D. & & 0.32 & 0.59 & 2.31 & 2.48 & 0.21 & 0.28 & 0.06 & 0.05 \\
\hline
\end{tabular}

Means with different letters are significantly different at $\mathrm{P}<0.05$.

Table 7. Effect of different nitrogen fertilization sources on flesh thickness, fruit moisture and TSS of Sakkoty dates during 2019 and 2020 seasons.

\begin{tabular}{|c|c|c|c|c|c|c|c|}
\hline & \multicolumn{2}{|c|}{ Fruit thickness (cm) } & \multicolumn{2}{|c|}{ Fruit moisture \% } & \multicolumn{2}{|c|}{ TSS \% } \\
\hline & & 2019 & 2020 & 2019 & 2020 & 2019 & 2020 \\
\hline $1-0.0 \%$ min. $+100 \%$ org. & $\left(T_{1}\right)$ & $0.32 \mathrm{~A}$ & $0.44 \mathrm{C}$ & $5.67 \mathrm{C}$ & $7.27 \mathrm{C}$ & $83.8 \mathrm{AB}$ & $80.7 \mathrm{~A}$ \\
\hline $2-50 \%$ min. $+50 \%$ org. & $\left(T_{2}\right)$ & $0.32 \mathrm{~A}$ & $0.47 \mathrm{~B}$ & $5.15 \mathrm{D}$ & $6.83 \mathrm{D}$ & $86.0 \mathrm{~A}$ & $81.0 \mathrm{~A}$ \\
\hline $\begin{array}{l}\text { 3- } 25 \% \text { min. }+25 \% \text { org. }+ \\
50 \% \text { bio. }\end{array}$ & $\left(T_{3}\right)$ & $0.31 \mathrm{~B}$ & $0.44 \mathrm{C}$ & $4.83 \mathrm{D}$ & $6.75 \mathrm{D}$ & $85.0 \mathrm{~A}$ & $82.8 \mathrm{~A}$ \\
\hline $\begin{array}{l}\text { 4- } 30 \% \text { min. }+35 \% \text { org. }+ \\
35 \% \text { bio. }\end{array}$ & $\left(T_{4}\right)$ & $0.33 \mathrm{~A}$ & $0.49 \mathrm{~A}$ & $5.44 \mathrm{C}$ & $7.22 \mathrm{C}$ & $85.5 \mathrm{~A}$ & $79.5 \mathrm{~A}$ \\
\hline $5-(100 \% \min -\mathrm{N})$ & $\left(T_{5}\right)$ & $0.29 \mathrm{C}$ & $0.38 \mathrm{D}$ & $6.63 \mathrm{~B}$ & $8.95 \mathrm{~B}$ & $81.5 \mathrm{~B}$ & $75.9 \mathrm{~B}$ \\
\hline $\begin{array}{l}\text { 6- } 50 \% \text { min. (farm treatment, } \\
\text { control) }\end{array}$ & $\left(T_{6}\right)$ & $0.28 \mathrm{C}$ & $0.35 \mathrm{E}$ & $8.35 \mathrm{~A}$ & $9.85 \mathrm{~A}$ & $65.8 \mathrm{C}$ & $66.9 \mathrm{C}$ \\
\hline L.S.D. & & 0.02 & 0.02 & 0.28 & 0.32 & 2.86 & 3.13 \\
\hline
\end{tabular}

Means with different letters are significantly different at $\mathrm{P}<0.05$.

Table 8. Effect of nitrogen fertilization source on sugar contents, acidity of Sakkoty dates during 2019 and 2020 seasons.

\begin{tabular}{|c|c|c|c|c|c|c|c|c|c|}
\hline & \multicolumn{2}{|c|}{ Total } & \multicolumn{2}{|c|}{ Reducing \% } & \multicolumn{2}{|c|}{ Non reducing } & \multicolumn{2}{|c|}{ Acidity } \\
\hline & & 2019 & 2020 & 2019 & 2020 & 2019 & 2020 & 2019 & 2020 \\
\hline $\min .+100 \%$ org. & $\left(T_{1}\right)$ & $66.88 \mathrm{~A}$ & $63.18 \mathrm{~A}$ & $32.83 \mathrm{~A}$ & $30.86 \mathrm{~A}$ & $34.05 \mathrm{~B}$ & $32.32 \mathrm{AB}$ & $0.26 \mathrm{C}$ & $0.23 \mathrm{C}$ \\
\hline $\min .+50 \%$ org. & $\left(T_{2}\right)$ & $68.93 \mathrm{~A}$ & $63.85 \mathrm{~A}$ & $33.48 \mathrm{~A}$ & $30.65 \mathrm{~A}$ & $35.45 \mathrm{~A}$ & $33.20 \mathrm{~A}$ & $0.25 \mathrm{CD}$ & $0.23 \mathrm{C}$ \\
\hline $\begin{array}{l}3-25 \% \text { min. }+25 \% \text { org. }+ \\
50 \% \text { bio. }\end{array}$ & $\left(T_{3}\right)$ & $67.23 \mathrm{~A}$ & $64.15 \mathrm{~A}$ & $32.93 \mathrm{~A}$ & $31.27 \mathrm{~A}$ & $34.30 \mathrm{AB}$ & $32.86 \mathrm{AB}$ & $0.24 \mathrm{D}$ & $0.21 \mathrm{DE}$ \\
\hline $\begin{array}{l}\text { 4- } 30 \% \text { min. }+35 \% \text { org. }+ \\
35 \% \text { bio. }\end{array}$ & $\left(T_{4}\right)$ & $.21 \mathrm{~A}$ & $62.84 \mathrm{~A}$ & 33.29A & $30.68 \mathrm{~A}$ & $34.92 \mathrm{AB}$ & $7 \mathrm{~B}$ & $.23 \mathrm{D}$ & $0.20 \mathrm{E}$ \\
\hline $\min -\mathrm{N})$ & $\left(T_{5}\right)$ & 64.63B & $60.20 \mathrm{~B}$ & $31.54 \mathrm{~B}$ & $29.45 \mathrm{~B}$ & $33.13 \mathrm{~B}$ & $30.75 \mathrm{C}$ & $0.28 \mathrm{~B}$ & $0.26 \mathrm{~B}$ \\
\hline $\begin{array}{l}\text { 6- 50\% min. (farm } \\
\text { control) }\end{array}$ & $\left(T_{6}\right)$ & $4.11 \mathrm{C}$ & $52.24 \mathrm{C}$ & $27.18 \mathrm{C}$ & $27.57 \mathrm{C}$ & $26.93 \mathrm{C}$ & $67 \mathrm{D}$ & $0.30 \mathrm{~A}$ & $0.27 \mathrm{~A}$ \\
\hline L.S.D. & & 2.15 & 2.08 & 1.25 & 1.11 & 1.19 & 0.98 & 0.01 & 0.01 \\
\hline
\end{tabular}

Means with different letters are significantly different at $\mathrm{P}<0.05$. 


\section{Discussion}

Nitrogen fertilization is one of the important tools to increase fruit trees yield. It plays a key role in nutrition of fruit trees that is a necessary element for chlorophyll, protoplasm and nucleic acids (Nijjar, 1985). The promotion on growth and nutritional status in response to application of organic- $\mathrm{N}$ and bio-fertilizers mainly may be attributed to their positive action on increasing the activity of micro flora, water holding capacity, soil structure, soil aggregation, organic matter, soil humus content and the availability of most nutrients. Also, such findings might be attributed to the effect of organic manure and biofertilizers on increasing the soil acidity, reducing the loss of nutrients with drainage water and enhancing the availability of nutrients in the soil. As well as, it can provide most nutrients to palm along the whole growth season. Such stimulation on the uptake of nutrients leads to enhancing the biosynthesis of organic foods and cell division (Yagodin, 1984; Miller et al., 1990; Kannainyan, 2002 and Yang et al., 2019).

It could be concluded that organic-N either alone or accompanied with inorganic and bio- $\mathrm{N}$ forms is beneficial to improve the growth and nutritional status of palms.

So, one can say that amending either by organic $\mathrm{N}$ only treatment or organic combined with bio plus mineral increased the yield components and regulated the annual yield. These results emphasized the vital importance of using organic manure as well as bio-fertilization in order to improve the bunch born, fruit set per- centage and bunch weight. Increasing the yield might be due improving the flower bud formation and fruit retention as well as decreasing the fruit drop as a response of organic manure and bio-form application.

There more, improvement of dates in terms of increasing total soluble solids and decreasing the moisture contents and total acidity due to organic nitrogen application either alone or combined with bio plus mineral nitrogen sources could be ascribed to a good balance between growth and fruiting and could be a result of accumulating more carbohydrates that makes them very available for enhancing ripening of dates.

These effects are very important in dates production since the improvement on dates quality is the most important target that induce an increase in packable yield and price.

Current study showed that fertilization with organic and biofertilizers significantly increased the leaf area for about $30 \%$ of leaf nitrogen for $37 \%$. Moreover, these fertilization applications significantly increased yield/palm for about $50 \%$ and fruit weight for $26 \%$ as well as significantly improved total soluble solids for about $26 \%$ and total sugars about for $23 \%$. Thus these treatments lead to increase the yield with good fruit quality which lead to the increase in packable yield.

These results are in agreement with those obtained by AbdelHameed and Ragab (2004), El-Assar (2005), El-Salhy et al. (2008), Alwasfy and El-Khawaga (2008), Ahmed et al. (2011), Saad et al. (2011), 
Abou Baker (2015), Omar (2015), ElSayed et al. (2016), Sayed-Maryam (2018) and Abdel-Kafy (2018). They reported that using organic and biofertilizers could improve the growth aspects followed by a gradual increase of the yield and improving the fruit quality of different palm date cultivars.

\section{Conclusion}

On the account of the present results, it could be concluded that fertilization the palms with triple form via 25-30 mineral-N and 25-35 organic along with $50-35 \%$ bio-form was very effective in improving the growth and nutritional status, as well as yield and fruit quality of Sakkoty date palm under the circumstance of this study. Additionally, it improves soil properties and reduces environmental pollution which could be occurred by excess of chemical fertilizers.

\section{References}

Abdel-Kafy, A.A.B. (2018). Effect of replacing inorganic $\mathrm{N}$ fertilizers partially using slow release $\mathrm{N}$ fertilizers as well as humic and fulvic acids on fruiting of Bartemuda date palms. Ph. D. Thesis Fgac. of Agric,. Minia Univ. Egypt.

Abdel-Hameed, M.A. and M.A. Ragab (2004). Response of Sewy date palm to application of some organic fertilizers. Abstract of the Second Inter. Conf. on Date Palm. Fac. Agric., El-Arish Sues Canal Univ., Egypt.

Abou-Baker, A.H.A. (2015). Effect of replacement of inorganic $\mathrm{N}$ fertilizer partially by using organic and biofertilization on productivity of Sakkoti date palms. M.Sc. Thesis Fac. of Agric. Minia Univ.

Ahmed, F.F.; A.M. Akl; E.A.H. ElMamlouk and H.H. Mohamed (2011). Reducing inorganic N fertilizers partially in Sakkoti date palm orchards by application of organic and biofertilization. Minia J. of Agric. Res. \& Develop. 31(2): 189-203.

Al-Wasfy, M.M.M. and A.S. ElKhawaga (2008). Effect of organic fertilization on growth, yield and fruit quality of Zaghloul date palms grown in sandy soil. Assiut J. of Agric. Sci. 39 (1): 121-133.

Association of Official Agricultural Chemists (1995). Official Methods of Analysis. A.O.A.C. $14^{\text {th }}$ ed. Published by A.O.A.C. Washington, D.C. U.S.A.

Bogatyre, A.N. (2000). What are we do to eat or how to live longer? Pishchevaya Promyshlennost, 78: 34-35.

Darwish, O.H., N. Persaud and D.C. Martens (1995). Effect of longterm application of animal manure on physical properties of three soils. Plant and Soil., 176: 289-285.

Devlin, R.M. and F.H. Withdam (1983). Plant Physiology. Renolds Book Corporation, New York (Chapter V).

Duncan, D.B. (1955). Moldable rang and moldable F-test. Biometrics. 11: 1-24.

El-Assar, A.M. (2005). Response of "Zaghloul" date yield and fruit characteristics to various organic and inorganic fertilization types as well as fruit thinning models in a rich carbonate soil. 
J. Agric. Sci. Mansoura Univ., 30 (5): 2795-2814.

El-Salhy, A.M. (2004). Organic farming in grapes production. The $2^{\text {nd }}$ Int. Conf. for Develop. and the Env. in Arab World, p. 393407.

El-Salhy, A.M.; H.A. Abdel-Galil; M.M. El-Akkad and Y.M. Diab (2008). Effect of mineral and organic nitrogen fertilization on vegetative growth, yield and fruit characteristics of Seewy date palms. 3rd Inter. Conf. for Date palms Agric. Sci. and Environ. Fac. Suez Canal Univ. 25 - 27 April.

El-Sayed, M.A.H.; A.H. Aly and A.Kh.M. Abdel-Wahab (2016). Effect of using humic acid and effective microorganisms as a partial replacement of mineral nitrogen fertilizer on fruiting of Seewy date palms. J. Biol. Chem. Environ. Sci. 11(3): 6085.

FAO, (2014). Quarterly Bulletin of Statistics 6 No. 113, 32 years Book. Annual 10 Prod. 46: 155157.

Gomez, K.A. and A.A. Gomez (1984). Statistical Procedures for Agriculture Research. $2^{\text {nd }}$ Ed. Wily, New York.

Kannaiyan, S. (2002). Biotechnology of bio-fertilizers Alpha Sci. Inter Ltd. P.O. Box 4067 Pang Bourne R.68. M.K. pp. 1-275.

Kenny, L. and I.A. Hassan (2006). Converting date palm ceases to organic farming: possibilities and constraints. Abstract of the Third International Date Palm Conf. Feb. $19^{\text {th }}-21^{\text {th }}$, Abu Dhabi.
Mertz, W. (1981). The essential trace elements. Science, 312, 1332.

Miller, E.W.; R.L. Donahue and J.U. Miller (1990). Soils "An Introduction to Soils and Plant Growth. 5 ed. Prentice Hall International Inc. Engle word Cliffs, New Jersey, 303- 339.

Nijjar, G.S. (1985). Nutrition of fruit trees. Mrs Usha Raj Kumar, Kalyani, New Delhi, pp. 10-20.

Omar, M.G.G. (2015). Response of Saidy date palms growing under New Valley conditions to some inorganic, organic and biofertilization as well as some antioxidant treatments. Ph.D. Thesis Fac. of Agric. Minia Univ. Egypt.

Osman, S. M. (2009). Response of Sakkoty date palm cultivar, propagated by tissue culture derived to different sources of fertilization. World J. of Agric. Sci. 5 (5): 631-638.

Russo, R.O. and G.P. Berlyn (1990). The use of organic biostimulants to help low input sustainable agriculture. J. Sust. Agr., 1: 19-42.

Saad, R.I.; Kh.A. Roshdy and A. Abd El- Mgeed-Nagwa (2011): Response of Zaghloul date palms grown in new reclaimed lands to application of organic and bionitrogen fertilizers. Alex. Sci. Exch. J. 31 (2): 121-129.

Sahrawat, K.L. (1979). Nitrogen losses in rice soils. Fert. News 24: 38-48.

Sayed- Maryam, M.A. (2018): Effect of using poultry manure tea enriched with EM as a partial replacement of inorganic Nitrogen on fruiting of Sakkoti date 
palms. M. Sc. Thesis Fac. of Agric. Minia. Univ. Egypt.

Shabana, H.R. and N.S. Antoun (1980). The determination of leaf area in date palm "Beitroya zur Tropischen Land Wirtschaft and Veterinar Medizin, 18 (4): 345-349. (c.f. Hort. Abst. 51: 9012).

Snedecor, G.W. and W.G. Cochran, (1990). Statistical Methods $7^{\text {th }}$ ed. Iowa State Univ. Press. Ames.

Subba Rao, N.S. (2004). Biofertilizers in Agriculture Oxford. IBH Company New Delhi.

Verna, L.N. (1990). Role of biotechnology in supplying plant nutrients in the vine ties. Fertilizer News, 35: 87-97.
Wilde, S.A., R.B. Corey, J.G. Lyer and G.K. Voigt (1985). Soil and plant analysis for tree cultivars. Oxford, IBH, New Delhi, India, pp. 94-105.

Wrigley, G. (1995). Date palm (Phoenix dectylifera (Palmae) pp 399-403 In: J. Smartt and N. W. Simmonds (eds.) Evolution of crop plants 2nd edition. Longman, UK.

Yagodin, B.A. (1984). Agricultural Chemistry, English Translation, Mir Publisher, Moscow.

Yang, X.; X. Chen and X. Yang (2019). Effect of organic matter on phosphorus adsorption and desorption in black soil from Northeast China. Soil Tillage Res., 187: 85-91. 


\section{تأثير التسميل العضوي والحيوي علي نمو و إثمار نخيل البلح السكوتي}

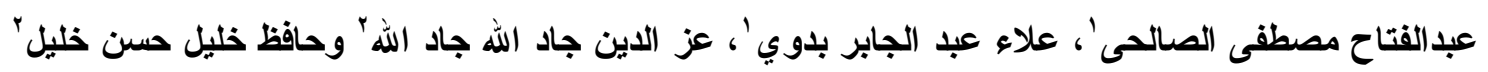

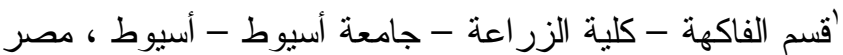

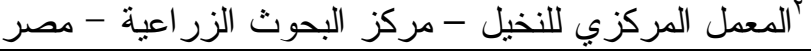

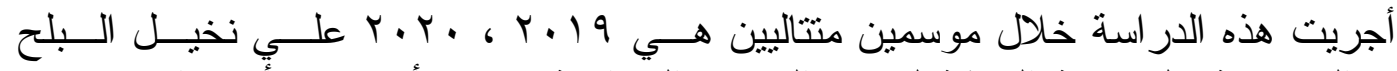

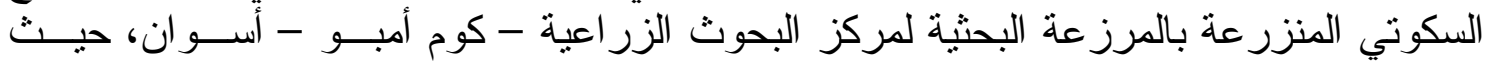

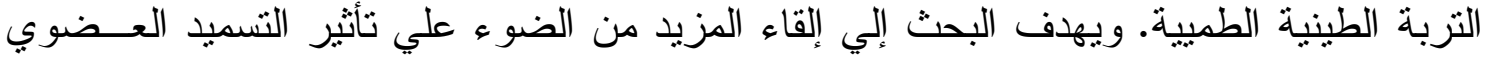

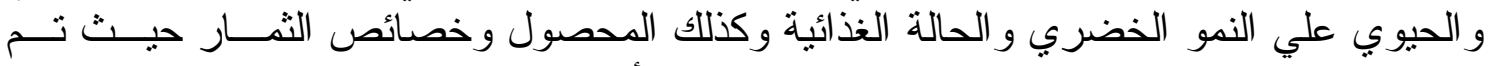

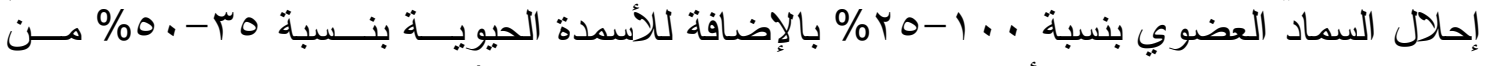

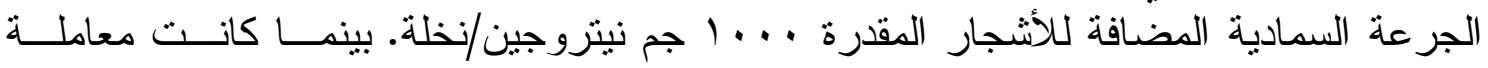

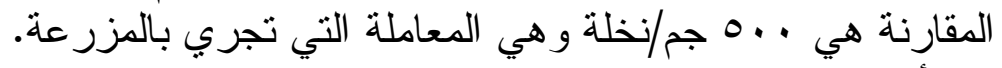

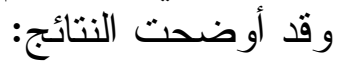

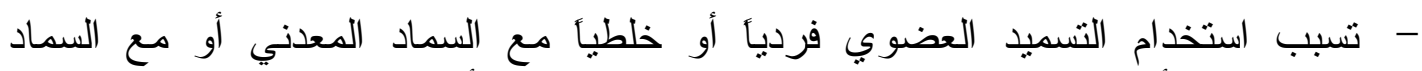

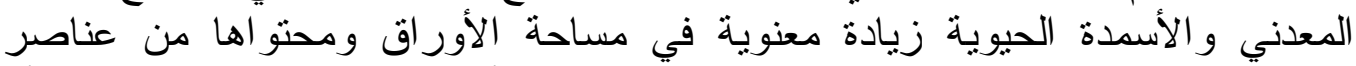

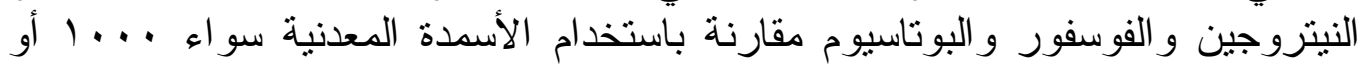

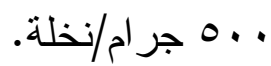

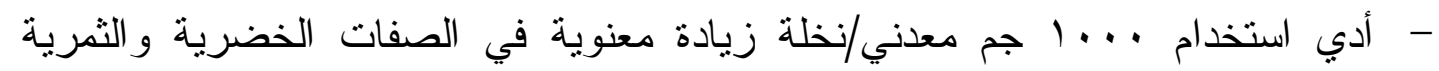
مقارنة باستخدام . . 0 جر ام معدني فقط.

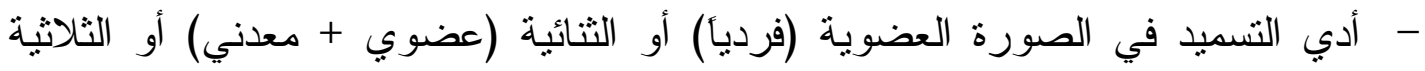

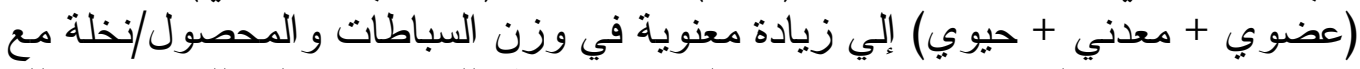

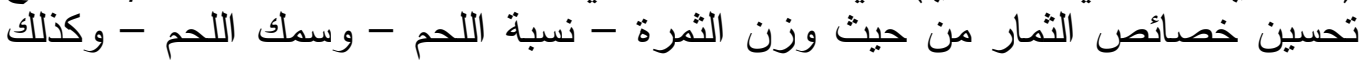
الصفات الكيميائية من حيث الموار من حاد الصلبة الكلية ومحتواهية من السكريات مقارنة بالتسميد المعدني فقط.

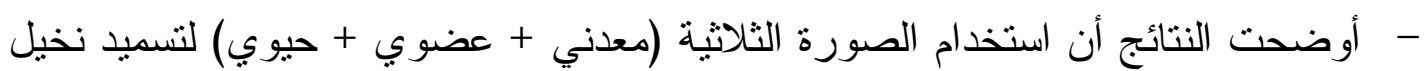

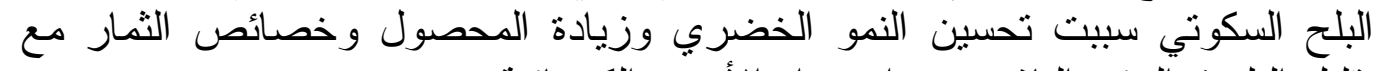
تقليل التلوث ألبيئي الناشئ عن استخدام الأسمدة الكيميائية. 